\title{
Sistem Pendukung Keputusan Pemilihan Mahasiswa Berprestasi dengan Metode Fuzzy TOPSIS
}

\author{
Dyah Herawatie $^{1)}$, Eto Wuryanto ${ }^{2)}$ \\ ${ }^{1)}$ Departemen Teknik, Fakultas Vokasi, Universitas Airlangga \\ Kampus B, Jl. Srikana 65, Surabaya \\ ${ }^{1)}$ dyah-herawatie@fst.unair.ac.id \\ ${ }^{1,2)}$ Departemen Matematika, Fakultas Sains dan Teknologi, Universitas Airlangga \\ Kampus C, Jl. Mulyorejo, Surabaya \\ ${ }^{2)}$ eto-w@fst.unair.ac.id
}

\begin{abstract}
Abstrak-Pemilihan mahasiswa berprestasi adalah kegiatan untuk memilih dan memberikan penghargaan kepada siswa yang mencapai kinerja tinggi dalam kurikuler, ko-kurikuler, maupun ekstrakurikuler. Kegiatan ini dilaksanakan secara berjenjang mulai dari tingkat program studi, departemen, fakultas, perguruan tinggi, hingga di tingkat nasional. Mawapres secara langsung atau tidak langsung dapat mengangkat martabat mahasiswa dan perguruan tingginya. Dalam proses seleksinya melibatkan pertimbangan atau kriteria yang sifatnya crisp : IPK, karya ilmiah, prestasi unggulan dan kemampuan bahasa Inggris. Tetapi dalam kenyataannya kriteria tersebut ada yang bersifat fuzzy, dengan demikian memungkinkan adanya kriteria bersifat campuran antara crisp dan fuzzy sehingga timbul kesulitan dalam melakukan pengurutan. Untuk mengatasi permasalahan yang ada diperlukan sistem pendukung keputusan dengan multi kriteria. Penelitian ini bertujuan untuk merancang dan membangun sistem pengambilan keputusan pemilihan mahasiswa berprestasi di Fakultas Vokasi Universitas Airlangga. Dari aplikasi ini bisa diperoleh hasil perangkingan selain dengan metode standard (sesuai pedoman Dikti), juga ditampilkan hasil perangkingan dengan metode TOPSIS, dan Fuzzy TOPSIS. Dengan beberapa alternatif perangkingan, diharapkan dapat memberi masukan buat pimpinan fakultas sebelum melakukan pengambilan keputusan. Dari 10 kandidat yang mengikuti seleksi pada tahun 2016, menunjukkan bahwa dengan menggunakan ketiga metode memberikan hasil yang berbeda untuk beberapa rangking. Sedangkan beberapa rangking yang lain sama. Terjadinya perbedaan ini disebabkan karena nilai dari beberapa kriteria dari kandidat berdekatan. Adanya perbedaan hasil perangkingan, saat memberikan masukan kepada pimpinan fakultas sebagai dasar pengambilan keputusan.
\end{abstract}

Kata Kunci- Fuzzy TOPSIS, Pemilihan Mahasiswa Vokasi Berprestasi, Sistem Pendukung Keputusan Abstract-Achievement student election is an activity to select and provide awards to students who reached high performance in curricular, co-curricular, and extracurricular. This activity is carried out gradually from the level of the study program, department, faculty, university, up to the national level. Achievement Student election directly or indirectly can raise the dignity of the students and the university. In the process of selection involves crisp consideration or criteria: GPA, scientific work, achievement seeded and English. Actually, there are one or more fuzzy criteria in this case. Since there are many criteria that is a mix between crisp and fuzzy cause difficulty in sorting process so that it becomes an interesting problem. To solve the problem, we need a decision support system with multi-criteria. This research aims to design and build a decision support system in achievement Student election at the Vocational Faculty of Airlangga University. From this application can be obtained the results of rank as an alternative to the standard method (according to the guidelines of Higher Education), also display a resulted rank from both TOPSIS method and Fuzzy TOPSIS. With some alternatives, rank can provide an important information for faculty leaders before making a decision. In 2016, the output of selection to 10 candidates shows that by using the three methods gave different results for some rank. There were differences are due to the value of some of the criteria of the adjacent candidate. The distinction of obtained rank can be a consideration to the faculty leaders in decision making.

Keywords-Achievement Student Election, Vocational Faculty of Airlangga University, Fuzzy TOPSIS

Article history:

Received 7 December 2016; Received in revised form 7 September 2017; Accepted 7 September 2017; Available online 28 October 2017

\section{PENDAHULUAN}

Pemilihan Mahasiswa Berprestasi (Mawapres) merupakan kegiatan rutin yang dilakukan setiap tahun oleh Dikti sejak tahun 2004. Kegiatan Mawapres merupakan kegiatan untuk memilih dan memberikan penghargaan kepada mahasiswa yang berhasil mencapai prestasi tinggi, baik kurikuler, kokurikuler, maupun ekstrakurikuler. Dengan kegiatan ini, mahasiswa diharapkan tidak hanya menekuni ilmu dalam bidangnya saja, tetapi juga beraktivitas untuk mengembangkan softskill- 
nya. Karena di dalam era persaingan bebas, dibutuhkan lulusan yang memiliki kemampuan hard skills dan soft skills yang seimbang. Oleh karena itu, di setiap perguruan tinggi (PT) perlu diidentifikasi mahasiswa yang dapat melakukan keduanya dan diberikan penghargaan sebagai mahasiswa yang berprestasi, yakni dengan melakukan seleksi mawapres di tingkat PT.

Prosedur Pemilihan Mawapres dilaksanakan secara berjenjang mulai dari tingkat program studi, departemen, fakultas, PT, hingga di nasional. Kegiatan Mawapres diselenggarakan dalam dua kelompok pemilihan, yaitu Mawapres Program Sarjana dan Diploma. Berdasarkan pedoman dari Dikti (BELMAWA RISTEKDIKTI, 2016), perbedaan penyelenggaraan terutama pada prosedur pemilihan dan atau cara penilaiannya.

Fakultas Vokasi merupakan fakultas yang ke-14 di Universitas Airlangga. Sebagai fakultas baru, Fakultas Vokasi mengelola seluruh program studi diploma yang ada di Universitas Airlangga. Saat ini Fakultas mengelola tujuh belas (17) Program Studi D-3, dan tiga (3) Program Studi D-4. Mulai tahun 2015, Fakultas Vokasi mengadakan kegiatan pemilihan Mawapres. Di dalam pelaksanaannya, fakultas telah mengikuti prosedur yang dikeluarkan Dikti. Dalam proses pengelolaan penilaiannya saat ini masih menggunakan excel.

Untuk memilih mahasiswa berprestasi, fakultas harus melakukannya secara hati-hati. Jika tidak, bisa menyebabkan kekeliruan dalam memilih mahasiswa yang mempunyai potensi tinggi untuk menang di tingkat nasional. Akibat yang lain adalah bisa merugikan fakultas dan univeritas. Karena dengan dipilihnya mahasiswa terbaik di tingkat Fakultas, dan mendapat persetujuan dari Universitas, kandidat terbaik akan dikirim untuk bersaing di tingkat nasional.

Dalam penelitian sebelumnya (Herawatie \& Wuryanto, 2016), dilakukan perangkingan dengan menggunakan TOPSIS (Technique for Order Preference by Similarity to Ideal Solution). Metode TOPSIS banyak digunakan untuk menyelesaikan masalah yang terkait dengan Multi Attribute Decision Making (MADM). Dijelaskan beberapa keunggulan dari TOPSIS, antara lain: konsepnya sederhana dan mudah dipahami, komputasinya efisien, dan memiliki kemampuan untuk mengukur kinerja relatif dari alternatif-alternatif keputusan dalam bentuk matematis sederhana (Hung \& Chen, 2009). Metode ini didasarkan pada konsep di mana alternatif terpilih yang terbaik tidak hanya memiliki jarak terpendek dari solusi ideal positif, namun juga memiliki jarak terpanjang dari solusi ideal negatif.

Dalam penelitian tersebut (Herawatie \& Wuryanto, 2016) digunakan data sepuluh (10) mahasiswa. Jika dibandingkan hasil perangkingan antara metode TOPSIS dengan rumus standard (skor masing-masing kriteria dikalikan bobotnya), perhitungan menunjukkan bahwa metode TOPSIS memberikan hasil yang sama untuk rangking 1 sampai 6 , dan rangking 10. Perbedaan terjadi pada rangking $7,8,9$. Hal ini disebabkan karena skor nilai ketiga posisi tersebut berdekatan.

Dalam penelitian ini akan digunakan Fuzzy TOPSIS untuk perangkingan. Digunakannya logika Fuzzy untuk merepresentasikan ketidakpastian, ketidakjelasan, ketidaktepatan, kekurangan informasi, dan kebenaran parsial. Beberapa metode lain yang bisa digunakan untuk data yang bersifat fuzzy antara lain Fuzzy Analytical Hierarchy Process (Fuzzy AHP), dan Fuzzy Simple Adaptive Weghting Method (Fuzzy SAW). perbandingan antara Fuzzy AHP dan Fuzzy TOPSIS, membuktikan bahwa hasil perangkingan untuk kedua metode menunjukkan hasil yang relatif sama (Alavi \& Alinajed-Rokny, 2011). Tetapi dalam beberapa hal, Fuzzy TOPSIS mempunyai keunggulan. Keunggulan tersebut antara lain Fuzzy AHP membutuhkan perhitungan yang lebih kompleks. Kedua metode juga terbukti bisa mengadopsi variabel linguistik.

Dalam beberapa tahun terakhir, beberapa peneliti juga menggunakan fuzzy TOPSIS untuk diaplikasikan dalam kasus yang berbeda. (Chu \& Lin, 2003) menerapkan Fuzzy TOPSIS untuk pemilihan robot. (Uyun \& Riadi, 2011), menggunakan Fuzzy TOPSIS untuk seleksi mahasiswa penerima beasiswa. Sedangkan (Wimatsari, Ketut, \& Putu, 2013), melakukan modifikasi Fuzzy TOPSIS dan menerapkan pada kasus yang sama. (Azizi, A. Aikhuele, \& Fathi S. Souleman, 2015), menggunakan Fuzzy TOPSIS untuk pemilihan supplier otomotif. (Liao \& Kao, 2011) mengintegrasikam Fuzzy TOPSIS dengan Multi-Choice Goal Programming (MCGP) untuk pemilihan supplier. (Kabir \& Hasin, 2012) menggunakan TOPSIS dan Fuzzy TOPSIS untuk memilih kuaitas layanan travel di Bangladesh, dan kemudian membandingkan hasilnya.

Bedasarkan permasalahan di atas, Fakultas Vokasi memerlukan aplikasi sistem pendukung keputusan untuk kegiatan pemilihan Mawapres. Untuk itu akan dibuat aplikasi, yang dapat mempermudah penilaian juri. Dalam aplikasi ini, sistem penilaiannya akan mengadopsi aturan-aturan yang ada di Dikti. Untuk penentuan kandidat terbaik, di dalam aplikasi selain ditampilkan rangking berdasarkan rumus standard, juga ditampilkan hasil perangkingan dengan menggunakan metode TOPSIS, dan Fuzzy TOPSIS. Untuk metode Fuzzy TOPSIS, akan digunakan beberapa kriteria yang bersifat 
campuran antara crisp dan fuzzy. Dengan beberapa alternatif perangkingan, diharapkan dapat memberi masukan buat pimpinan Fakultas sebelum melakukan pengambilan keputusan.

\section{METODE PENELITIAN}

Langkah-langkah yang dilakukan untuk mendapatkan penyelesaian masalah adalah sebagai berikut :

\section{A. Analisis Aturan}

Menganalisis aturan-aturan penilaian dengan mengacu pada pedoman pemilihan mawapres program diploma yang dikeluarkan oleh DIKTI. Adapun kriteria pemilihannya terdiri atas lima unsur, yaitu : IP Kumulatif, Karya tulis, Pencapaian prestasi yang diunggulkan, Kemampuan berbahasa Inggris atau berbahasa lain yang menjadi bahasa resmi PBB, dan Kepribadian.

Untuk pemilihan Mawapres Diploma, maka bidang penilaian dibatasi pada rumpun ilmu terapan, yang dibagi menjadi bidang Rekayasa dan bidang Non Rekayasa.

\section{B. Penerapan metode fuzzy TOPSIS}

Menerapkan metode Fuzzy TOPSIS untuk menyelesaikan masalah pemilihan Mawapres. Langkah-langkah analisis menggunakan fuzzy TOPSIS menurut (Awasthi, Chauhan, \& Goyal, 2011) dan (Chen, Lin, \& Huang, 2006), adalah sebagai berikut:

Menentukan nilai kriteria untuk setiap alternatif kandidat, dan sifat masing-masing kriteria apakah termasuk crisp atau fuzzy

TABEL 1. Nilai VARiabel Linguistik UNTUK BOBOT

\begin{tabular}{cc}
\hline \hline Variabel Linguistik & $\begin{array}{c}\text { Fungsi } \\
\text { Keanggotaan }\end{array}$ \\
\hline Sangat Tidak Penting (STP) & $(0,0,0,1,0,2)$ \\
Tidak Penting (TP) & $(0.1,0,2,0,2,0,3)$ \\
Cukup Tidak Penting (CTP) & $(0.2,0,3,0,4,0,5)$ \\
Cukup (C) & $(0.4,0,5,0,5,0,6)$ \\
Cukup Penting (CP) & $(0.5,0,6,0,7,0,8)$ \\
Penting (P) & $(0.7,0.8,0.8,0,9)$ \\
Sangat Penting (SP) & $(0.8,0.9,1,1)$ \\
\hline \hline
\end{tabular}

TABEL 2. Nilai VARIABEL LingUistik UNTUK RATING

\begin{tabular}{cc}
\hline \hline Variabel Linguistik & $\begin{array}{c}\text { Fungsi } \\
\text { Keanggotaan }\end{array}$ \\
\hline Sangat Tidak Baik (STB) & $(0,0,0,1,0,2)$ \\
Tidak Baik (TB) & $(0.1,0,2,0,2,0,3)$ \\
Cukup Tidak Baik (CTB) & $(0.2,0,3,0,4,0,5)$ \\
Cukup (C) & $(0.4,0,5,0,6,0,7)$ \\
Cukup Baik (CB) & $(0.5,0,6,0,7,0,8)$ \\
Baik (B) & $(0.7,0.8,0.8,0,9)$ \\
Sangat Baik (SB) & $(0.8,0.9,1,1)$ \\
\hline \hline
\end{tabular}

Dalam kriteria yang bersifat fuzzy akan ditentukan variabel linguistik yang sesuai untuk bobot kriteria dan rating linguistik untuk alternatif kandidat. Dalam penelitian ini nilai variabel lingustik diekspresikan dalam bilangan fuzzy trapesoid positif. Variabel lingustik yang digunakan untuk bobot kriteria dapat dilihat pada tabel 1. Sedangkan untuk rating dapat dilihat pada tabel 2. (Liao \& Kao, 2011).

Menghitung Aggregate Fuzzy Rating untuk kriteria dan alternative. Menghitung Matriks Keputusan. Menghitung matriks keputusan ternormalisasi. Menghitung matriks keputusan normalisasi terbobot. Menghitung nilai fuzzy solusi ideal positif $\mathrm{A}^{+}$dan fuzzy solusi ideal negatif $\mathrm{A}^{-}$. Menghitung jarak antara nilai pada setiap alternatif dengan Fuzzy Positive Ideal Solution ( FPIS) dan Fuzzy Negative Ideal Solution (FNIS). Menghitung nilai closeness coefficient $\left(\mathrm{CC}_{\mathrm{i}}\right)$ untuk setiap alternatif. Merangking alternatif, berdasarkan nilai $\mathrm{CC}_{\mathrm{i}}$, Alternatif yang memiliki nilai $\mathrm{CC}_{\mathrm{i}}$ tertinggi merupakan pilihan lokasi terbaik.

\section{Membandingkan hasil perangkingan}

Membandingkan hasil perangkingan yang diperoleh dengan perhitungan standard, TOPSIS, dan Fuzzy TOPSIS.

\section{Perancangan Sistem}

Dalam perancangan sistem yang dibuat adalah: System Flow Chart atau Diagram Alir, yaitu diagram yang menggambarkan aliran proses dari suatu sistem. Dan Perancangan database secara logika Conceptual Data Model (CDM).

\section{E. Implementasi Sistem}

Sistem akan diimplementasikan dengan menggunakan bahasa pemrograman PHP, dan database yang digunakan adalah MySQL.

\section{F. Evaluasi Sistem}

Evaluasi sistem dilakukan bertujuan untuk mengetahui bagaimana kepuasan user terhadap fitur yang terdapat dalam sistem serta memastikan hasil yang dikeluarkan oleh. Aplikasi sesuai dengan yang diharapkan.

\section{HASIL DAN PEMBAHASAN}

Proses pemilihan berprestasi di Fakultas Vokasi telah dilaksanakan pada tanggal 27 Agustus 2016. Dari pendaftaran yang dibuka sejak bulan Juli 2016, mahasiswa yang mendaftar sebanyak 13 orang. Dari 13 mahasiswa yang mendaftar, sebanyak 10 orang yang mengikuti proses seleksi. Sedangkan 3 mahasiswa yang lain, tidak mengikuti proses seleksi dengan alasan kesibukan yang tidak bisa ditinggalkan.

Dalam proses pelaksanaannya Fakultas Vokasi mengadopsi prosedur yang digunakan pada proses seleksi di tingkat nasional, seperti yang tertuang di buku pedoman Dikti 
(BELMAWA RISTEKDIKTI, 2016). Penilaian dilakukan dalam dua tahap, yaitu penilaian awal (desk evaluation) dan penilaian akhir (presentasi dan wawancara). Unsur-unsur yang dinilai adalah: Karya tulis ( $40 \%$ naskah/tulisan, $60 \%$ presentasi), Prestasi /kemampuan yang diunggulkan ( $40 \%$ dokumen, $60 \%$ wawancara), Bahasa Inggris/asing ( $40 \%$ Ringkasan, 60\% Presentasi dan Diskusi), dan Kepribadian.

Berdasarkan hasil seleksi diperoleh data seperti pada Tabel 3. Nilai mahasiswa untuk keempat kriteria ini diubah menjadi skala 100. Selanjutnya masing-masing nilai untuk setiap kriteria dikalikan dengan bobotnya untuk menentukan nilai total yang diperoleh mahasiswa. Nilai total tertinggi akan menentukan Mawapres terbaik.

TABEL 3. NILAI MAHASISWA UNTUK TIAP KRITERIA

\begin{tabular}{clrrr}
\hline \hline Mahasiswa & \multicolumn{4}{c}{ Kriteria } \\
\cline { 2 - 5 } & IPK & \multicolumn{1}{c}{ KTI } & PKYD & \multicolumn{1}{c}{ KBI } \\
\hline A & 96,00 & 62,79 & 45,96 & 74,50 \\
B & 94,00 & 65,72 & 50,09 & 77,40 \\
C & 83,50 & 100 & 79,00 & 94,40 \\
D & 88,50 & 63,86 & 68,01 & 46.00 \\
E & 89,75 & 75,24 & 60,61 & 82,25 \\
F & 88,75 & 71,86 & 53,58 & 45,67 \\
G & 89,00 & 94,81 & 100 & 79,45 \\
H & 89,25 & 78,57 & 43,40 & 62,21 \\
I & 86,25 & 87,73 & 91,12 & 100 \\
J & 88,25 & 82,57 & 91,08 & 64,50 \\
\hline \hline
\end{tabular}

Keterangan:

IPK = Indeks Prestasi Kumulatif

$\mathrm{KTI}=$ Karya Tulis Ilmiah

$\mathrm{KBI}=$ Kemampuan Bahasa Inggris

$\mathrm{PKYD}=$ Prestasi/Kemampuan yang diunggulkan

Adapun bobot masing-masing kriteria adalah sebagai berikut : IPK, dengan bobot $20 \%$; Karya tulis yang terdiri atas nilai tulisan dan presentasi, dengan bobot 35\%; Prestasi/Kemampuan yang diunggulkan, dengan bobot $25 \%$; dan Bahasa Inggris, dengan bobot $20 \%$.

Dalam menyelesaikan masalah pemilihan Mawapres dengan metode Fuzzy TOPSIS, langkah pertama yang dilakukan adalah menentukan di antara kriteria-kriteria yang digunakan bersifat crisp atau fuzzy. Pada penelitian ini kriteria IPK dianggap bilangan crisp, sedangkan kriteria yang lain dianggap bilangan fuzzy (KTI, PKYD, dan KBI). Langkah selanjutnya adalah mengubah data hasil penilaian pada Tabel 3 menjadi variabel linguistik. Nilai variabel linguistik dinyatakan dalam bilangan fuzzy trapezoidal. Dengan menggunakan Tabel 2, nilai kesepuluh calon peserta yang ada pada Tabel 3 dengan 4 kriteria ( 3 bersifat fuzzy dan 1 bersifat crisp), diubah ke dalam nilai variabel linguistik. Matriks data nilai yang baru bisa dilihat pada Tabel 4. Bobot setiap kriteria yang telah ditentukan besarannya juga diubah menjadi variabel linguistik. Bobot tersebut diubah menjadi vektor bobot w berdasarkan Tabel 1 dan hasilnya dapat dilihat pada Tabel 5 .

TABEL 4. NiLAI VARIABEL LINGUISTIK

\begin{tabular}{ccccc}
\hline \hline Mahasiswa & \multicolumn{4}{c}{ Kriteria } \\
\cline { 2 - 5 } & IPK & KTI & PKYD & KBI \\
\hline A & 96,00 & C & TB & CB \\
B & 94,00 & C & CTB & CB \\
C & 83,50 & SB & CB & SB \\
D & 88,50 & C & C & TB \\
E & 89,75 & CB & C & B \\
F & 88,75 & CB & CTB & TB \\
G & 89,00 & SB & SB & CB \\
H & 89,25 & CB & TB & CB \\
I & 86,25 & B & SB & SB \\
J & 88,25 & B & SB & C \\
\hline
\end{tabular}

TABEL 5. VEKTOR BOBOT

\begin{tabular}{|c|c|c|c|c|c|c|c|c|c|c|c|c|c|c|c|c|}
\hline \multicolumn{5}{|c|}{ IPK } & \multicolumn{4}{|c|}{ KTI } & \multicolumn{4}{|c|}{ PKYD } & \multicolumn{4}{|c|}{ KBI } \\
\hline $\mathrm{W}$ & 0,01 & 0,2 & 0,2 & 0.3 & 0.2 & 0.3 & 0.4 & 0.5 & 0.2 & 0.3 & 0.4 & 0.5 & 0.1 & 0.2 & 0.2 & 0.3 \\
\hline
\end{tabular}

TABEL 6. MATRIKS KEPUTUSAN FUZZY TERNORMALISASI

\begin{tabular}{ccccccccccccccccc}
\hline \hline \multicolumn{3}{c}{ IPK } & \multicolumn{4}{c}{ KTI } \\
\hline A & 1.00 & 1.00 & 1.00 & 1.00 & 0.40 & 0.50 & 0.50 & 0.60 & 0.10 & 0.20 & 0.20 & 0.30 & 0.50 & 0.60 & 0.70 & 0.80 \\
B & 0.98 & 0.98 & 0.98 & 0.98 & 0.40 & 0.50 & 0.50 & 0.60 & 0.20 & 0.30 & 0.40 & 0.50 & 0.50 & 0.60 & 0.70 & 0.80 \\
C & 0.87 & 0.87 & 0.87 & 0.87 & 0.80 & 0.90 & 1.00 & 1.00 & 0.50 & 0.60 & 0.70 & 0.80 & 0.80 & 0.90 & 1.00 & 1.00 \\
D & 0.92 & 0.92 & 0.92 & 0.92 & 0.40 & 0.50 & 0.50 & 0.60 & 0.40 & 0.50 & 0.50 & 0.60 & 0.10 & 0.20 & 0.20 & 0.30 \\
E & 0.93 & 0.93 & 0.93 & 0.93 & 0.50 & 0.60 & 0.70 & 0.80 & 0.40 & 0.50 & 0.50 & 0.60 & 0.70 & 0.80 & 0.80 & 0.90 \\
F & 0.92 & 0.92 & 0.92 & 0.92 & 0.50 & 0.60 & 0.70 & 0.80 & 0.20 & 0.30 & 0.40 & 0.50 & 0.10 & 0.20 & 0.20 & 0.30 \\
G & 0.93 & 0.93 & 0.93 & 0.93 & 0.80 & 0.90 & 1.00 & 1.00 & 0.80 & 0.90 & 1.00 & 1.00 & 0.50 & 0.60 & 0.70 & 0.80 \\
H & 0.93 & 0.93 & 0.93 & 0.93 & 0.50 & 0.60 & 0.70 & 0.80 & 0.10 & 0.20 & 0.20 & 0.30 & 0.40 & 0.50 & 0.50 & 0.60 \\
I & 0.90 & 0.90 & 0.90 & 0.90 & 0.70 & 0.80 & 0.80 & 0.90 & 0.80 & 0.90 & 1.00 & 1.00 & 0.80 & 0.90 & 1.00 & 1.00 \\
J & 0.92 & 0.92 & 0.92 & 0.92 & 0.70 & 0.80 & 0.80 & 0.90 & 0.80 & 0.90 & 1.00 & 1.00 & 0.40 & 0.50 & 0.50 & 0.60 \\
\hline \hline
\end{tabular}


TABEL 7. MATRIKS KEPUTUSAN FUZZY TERNORMALISASI DAN TERBOBOTI

\begin{tabular}{cccccccccccccccccc}
\hline \hline & \multicolumn{3}{c}{ IPK } & \multicolumn{3}{c}{ KTI } & \multicolumn{3}{c}{ PKYD } & \multicolumn{4}{c}{ PBI } \\
\hline A & 0.10 & 0.20 & 0.20 & 0.30 & 0.08 & 0.15 & 0.20 & 0.30 & 0.02 & 0.06 & 0.08 & 0.15 & 0.05 & 0.12 & 0.14 & 0.24 \\
B & 0.10 & 0.20 & 0.20 & 0.29 & 0.08 & 0.15 & 0.20 & 0.30 & 0.04 & 0.09 & 0.16 & 0.25 & 0.05 & 0.12 & 0.14 & 0.24 \\
C & 0.09 & 0.17 & 0.17 & 0.26 & 0.16 & 0.27 & 0.40 & 0.50 & 0.10 & 0.18 & 0.28 & 0.40 & 0.08 & 0.18 & 0.20 & 0.30 \\
D & 0.09 & 0.18 & 0.18 & 0.28 & 0.08 & 0.15 & 0.20 & 0.30 & 0.08 & 0.15 & 0.20 & 0.30 & 0.01 & 0.04 & 0.04 & 0.09 \\
E & 0.09 & 0.19 & 0.19 & 0.28 & 0.10 & 0.18 & 0.28 & 0.40 & 0.08 & 0.15 & 0.20 & 0.30 & 0.07 & 0.16 & 0.16 & 0.27 \\
F & 0.09 & 0.18 & 0.18 & 0.28 & 0.10 & 0.18 & 0.28 & 0.40 & 0.04 & 0.09 & 0.16 & 0.25 & 0.01 & 0.04 & 0.04 & 0.09 \\
G & 0.09 & 0.19 & 0.19 & 0.28 & 0.16 & 0.27 & 0.40 & 0.50 & 0.16 & 0.27 & 0.40 & 0.50 & 0.05 & 0.12 & 0.14 & 0.24 \\
H & 0.09 & 0.19 & 0.19 & 0.28 & 0.10 & 0.18 & 0.28 & 0.40 & 0.02 & 0.06 & 0.08 & 0.15 & 0.04 & 0.10 & 0.10 & 0.18 \\
I & 0.09 & 0.18 & 0.18 & 0.27 & 0.14 & 0.24 & 0.32 & 0.45 & 0.16 & 0.27 & 0.40 & 0.50 & 0.08 & 0.18 & 0.20 & 0.30 \\
J & 0.09 & 0.18 & 0.18 & 0.28 & 0.14 & 0.24 & 0.32 & 0.45 & 0.16 & 0.27 & 0.40 & 0.50 & 0.04 & 0.10 & 0.10 & 0.18 \\
\hline \hline
\end{tabular}

Selanjutnya untuk mendapatkan matriks keputusan fuzzy ternormalisasi ditentukan dengan cara : Jika nilai kriterianya berupa bilangan/numeric, maka perlu dilihat kriteria tersebut bersifat benefit atau cost dan perhitungan dapat dilakukan dengan menggunakan rumus yang sesuai.Jika nilai kriterianya berupa variabel linguistik, maka mengkonversi nilai variabel linguistik di Tabel 4 ke dalam bilangan fuzzy trapezoidal yang tertera di Tabel 2. Hasilnya dapat dilihat di Tabel 6.

Untuk mendapatkan Matriks Keputusan Fuzzy Ternormalisasi yang terboboti dilakukan dengan cara mengalikan setiap elemen baris dari Matriks Keputusan Fuzzy Ternormalisasi yang bersesuaian dengan vektor bobot. Hasilnya bisa dilihat pada Tabel 7.

TABEL 8. MATRIKS M

\begin{tabular}{ccccc}
\hline \hline & IPK & KTI & PKYD & KBI \\
\hline A & 0.20 & 0.18 & 0.08 & 0.14 \\
B & 0.20 & 0.18 & 0.14 & 0.14 \\
C & 0.17 & 0.33 & 0.24 & 0.19 \\
D & 0.18 & 0.18 & 0.18 & 0.05 \\
E & 0.19 & 0.24 & 0.18 & 0.17 \\
F & 0.18 & 0.24 & 0.14 & 0.05 \\
G & 0.19 & 0.33 & 0.33 & 0.14 \\
H & 0.19 & 0.24 & 0.08 & 0.11 \\
I & 0.18 & 0.29 & 0.33 & 0.19 \\
J & 0.18 & 0.29 & 0.33 & 0.11 \\
\hline \hline
\end{tabular}

Dalam penghitungan nilai fuzzy solusi ideal positif $\mathrm{A}^{+}$dan fuzzy solusi ideal negatif $\mathrm{A}^{-}$ diperlukan matriks $M$ yang digunakan untuk menentukan nilai $\mathrm{A}^{+}$dan $\mathrm{A}^{-}$. Jika kriterianya bersifat benefit maka letak nilai maksimum di kolom kriteria tersebut akan menjadi nilai $\mathrm{A}^{+}$ dan letak nilai minimum di kolom kriteria tersebut akan menjadi nilai $\mathrm{A}^{-}$. Sementara jika kriterianya bersifat cost maka letak nilai minimum di kolom kriteria tersebut akan menjadi nilai $\mathrm{A}^{+}$dan letak nilai maksimum di kolom kriteria tersebut akan menjadi nilai $\mathrm{A}^{-}$. Matriks M selengkapnya dapat dilihat di Tabel 8.
Untuk menentukan Nilai fuzzy solusi ideal positif $\mathrm{A}^{+}$dan fuzzy solusi ideal negatif $\mathrm{A}^{-}$ dilakukan seperti berikut. Misal untuk kriteria IPK yang bersifat benefit nilai maksimum = 0.20 dan minimum $=0.17$ maka letak nilai maksimumnya berada di baris pertama maka nilai yang berada di baris A dan kolom IPK menjadi nilai $\mathrm{A}^{+}$dan letak nilai minimum terletak di baris ketiga maka nilai yang berada di baris $\mathrm{C}$ dan kolom IPK menjadi nilai $\mathrm{A}^{-}$. Nilai fuzzy solusi ideal positif dan negatifnya bisa dilihat pada Tabel 9.

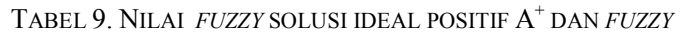
SOLUSI IDEAL NEGATIF A $\mathrm{A}^{-}$

\begin{tabular}{llllll}
\hline \hline IPK & $\mathbf{A}^{+}$ & $\mathbf{0 . 1 0}$ & $\mathbf{0 . 2 0}$ & $\mathbf{0 . 2 0}$ & $\mathbf{0 . 3 0}$ \\
\hline \multirow{4}{*}{ KTI } & $\mathrm{A}^{-}$ & 0.09 & 0.17 & 0.17 & 0.26 \\
& $\mathrm{~A}^{+}$ & 0.16 & 0.27 & 0.40 & 0.50 \\
PKYD & $\mathrm{A}^{-}$ & 0.08 & 0.15 & 0.20 & 0.30 \\
& $\mathrm{~A}^{+}$ & 0.16 & 0.27 & 0.40 & 0.50 \\
KBI & $\mathrm{A}^{-}$ & 0.02 & 0.06 & 0.08 & 0.15 \\
& $\mathrm{~A}^{+}$ & 0.08 & 0.18 & 0.20 & 0.30 \\
& $\mathrm{~A}^{-}$ & 0.01 & 0.04 & 0.04 & 0.09 \\
\hline \hline
\end{tabular}

Tahap berikutnya adalah Menghitung jarak antara nilai pada setiap alternatif dengan Fuzzy Positive Ideal Solution (FPIS) dan Fuzzy Negative Ideal Solution (FNIS) yang masingmasing hasilnya dapat dilihat di Tabel 10 dan Tabel 11.

TABEL 10. NILAI JARAK ANTARA NILAI PADA SETIAP ALTERNATIF DENGAN FUZZY POSITIVE IDEAL SOLUTION

\begin{tabular}{ccccc}
\hline \hline & IPK & KTI & PKYD & KBI \\
\hline A & 0.00 & 0.33 & 1.00 & 0.20 \\
B & 0.02 & 0.33 & 0.55 & 0.20 \\
C & 0.14 & 0.00 & 0.00 & 0.00 \\
D & 0.08 & 0.33 & 0.33 & 0.93 \\
E & 0.07 & 0.00 & 0.33 & 0.10 \\
F & 0.08 & 0.00 & 0.55 & 0.93 \\
G & 0.08 & 0.00 & 0.00 & 0.20 \\
H & 0.07 & 0.00 & 1.00 & 0.44 \\
$\mathbf{I}$ & 0.11 & 0.00 & 0.00 & 0.00 \\
$\mathbf{J}$ & 0.08 & 0.00 & 0.00 & 0.44 \\
\hline \hline
\end{tabular}




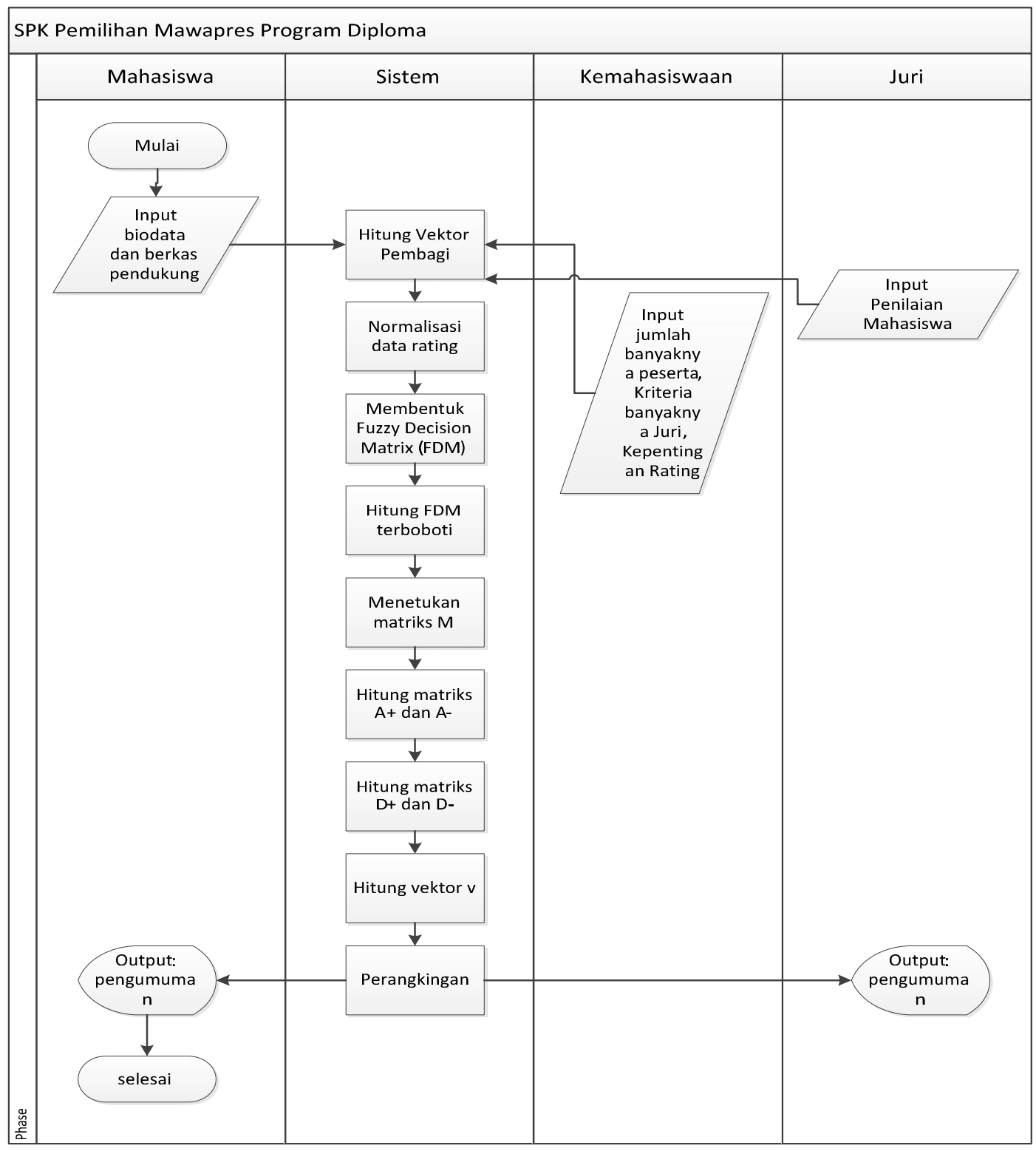

Gambar 1. Flowchart SPK Pemilihan Mawapres

TABEL 11. NILAI JARAK ANTARA NILAI PADA SETIAP ALTERNATIF DENGAN FUZZY NEGATIVE IDEAL SOLUTION

\begin{tabular}{ccccc}
\hline \hline & IPK & KTI & PKYD & KBI \\
\hline A & 0.14 & 0.00 & 0.00 & 0.67 \\
B & 0.12 & 0.00 & 0.08 & 0.67 \\
C & 0.00 & 0.33 & 0.67 & 0.93 \\
D & 0.06 & 0.00 & 0.50 & 0.00 \\
E & 0.07 & 0.00 & 0.50 & 0.86 \\
F & 0.06 & 0.00 & 0.08 & 0.00 \\
G & 0.06 & 0.33 & 1.00 & 0.67 \\
H & 0.07 & 0.00 & 0.00 & 0.55 \\
I & 0.03 & 0.20 & 1.00 & 0.93 \\
J & 0.06 & 0.20 & 1.00 & 0.55 \\
\hline \hline
\end{tabular}

Sebelum melakukan perangkingan terlebih dahulu dilakukan penghitungan nilai closeness coefficient $\left(\mathrm{CC}_{\mathrm{i}}\right)$ untuk setiap alternatif yang hasilnya diperlihatkan di Tabel 12.

Tahap terakhir adalah mengurutkan atau merangking alternatif berdasarkan nilai $\mathrm{CC}_{\mathrm{i}}$ di
Tabel 12. Rangking 1 adalah kandidat mahasiswa yang memiliki nilai $\mathrm{CC}_{\mathrm{i}}$ tertinggi, rangking 2 adalah tertinggi berikutnya, dan seterusnya. Jika hasil perangkingan dengan menggunakan metode Fuzzy TOPSIS dibandingkan dengan dua metode sebelumnya standard dan TOPSIS (Herawatie \& Wuryanto, 2016), hasilnya bisa dilihat pada Tabel 12.

Dengan melihat hasil perangkingan Fuzzy TOPSIS, Terdapat perbedaan hasil pengurutan atau perangkingan yang signifikan. Jika dilihat hasil perangkingan dengan metode fuzzy TOPSIS, yang menjadi rangking 1 adalah mhs I, yang dengan menggunakan metode standard dan TOPSIS berada di urutan ke 2. Mahasiswa C, G, I, secara berbeda berada di rangking 1, 2, dan 3. Hasil yang berbeda juga terjadi pada mahasiswa A, D, dan $\mathrm{H}$, yang berada di 
TABel 12. Perbandingan Hasil Perangkingan metode STANDARD DENGAN TOPSIS

\begin{tabular}{ccccccc}
\hline \hline MHS & $\begin{array}{c}\text { Skor } \\
\text { Standard }\end{array}$ & $\begin{array}{c}\text { Prefer } \\
\text { (TOPSIS) }\end{array}$ & $\begin{array}{c}\mathbf{C C}_{\mathbf{i}} \\
\text { (Fuzzy } \\
\text { TOPSIS) }\end{array}$ & $\begin{array}{c}\text { Rangking } \\
\text { Standard }\end{array}$ & $\begin{array}{c}\text { Rangking } \\
\text { TOPSIS }\end{array}$ & $\begin{array}{c}\text { Rangking } \\
\text { Fuzzy } \\
\text { TOPSIS }\end{array}$ \\
\hline $\mathbf{A}$ & 67,5665 & 0,2409 & 0.34 & 8 & 9 & 7 \\
B & 69,8045 & 0,2778 & 0.44 & 6 & 6 & 6 \\
$\mathbf{C}$ & 90,3300 & 0,7524 & 0.93 & 3 & 3 & 2 \\
$\mathbf{D}$ & 66,2535 & 0,2640 & 0.25 & 9 & 7 & 9 \\
E & 75,8865 & 0,4119 & 0.74 & 5 & 5 & 5 \\
F & 65,4300 & 0,1790 & 0.08 & 10 & 10 & 10 \\
G & 91,8735 & 0,8088 & 0.88 & 1 & 1 & 3 \\
H & 68,6415 & 0,2559 & 0.29 & 7 & 8 & 8 \\
I & 90,7355 & 0,7892 & 0.95 & 2 & 4 & 4 \\
$\mathbf{J}$ & 82,2195 & 0,6059 & 0.77 & 4 & 4 & 4 \\
\hline \hline
\end{tabular}

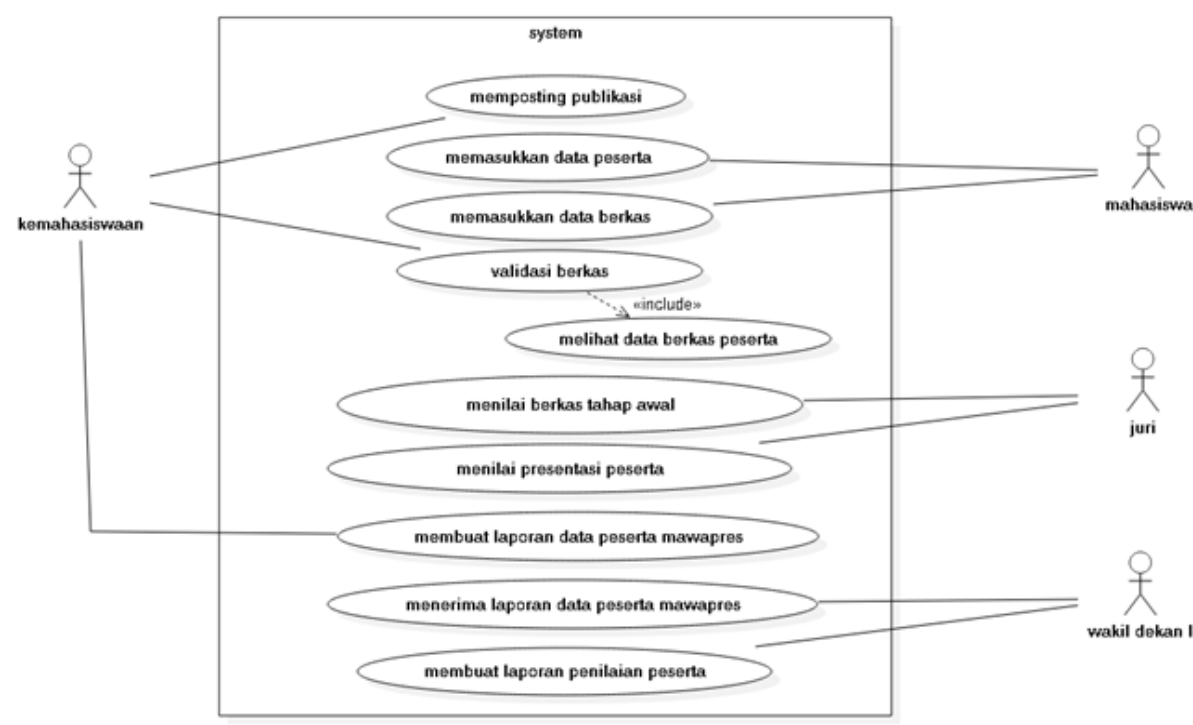

Gambar 2. Diagram use case

rangking 7, 8, 9. Sedangkan mahasiswa $\mathrm{B}, \mathrm{E}, \mathrm{F}$, $\mathrm{J}$, tetap pada rangking 4, 5, 6, dan 10 .

Dalam (Kabir \& Hasin, 2012) juga memperoleh hasil perangkingan yang tidak semuanya sama. Dalam penelitian tersebut dijelaskan bahwa karena sifat dari MADM terkait masalah yang diajukan, tidak akan diperoleh solusi optimum. Tetapi hasil dari perangkingan ini dapat digunakan untuk mengevaluasi secara sistematis dan untuk mengurangi risiko pemilihan kualitas layanan yang buruk. Dalam penelitian ini juga dijelaskan bahwa metode TOPSIS merupakan pendekatan yang tepat digunakan jika penilaian kinerja secara tepat tersedia. Sedangkan metode fuzzy TOPSIS merupakan pilihan yang lebih disukai jika penilaian kinerjanya tidak tepat atau tidak jelas.

Beberapa faktor yang mempengaruhi perbedaan hasil perangkingan dalam masalah seleksi mawapres ini selain disebabkan karena nilai kriteria, bobot kriteria, juga sifat dari kriteria. Adanya perbedaan hasil perangkingan, dapat memberikan masukan kepada pimpinan fakultas untuk dasar pengambilan keputusan.

Untuk memudahkan proses pemilihan mawapres, dibuat aplikasi dengan flowchart dan diagram use case, yang masing-masing bisa dilihat pada gambar 1 dan 2 .

Dalam sistem ini, terdapat empat aktor yang terlibat antara lain:

1) Peserta: yang dalam hal ini mahasiswa: mempunyai hak akses untuk melakukan registrasi atau mendaftar sebagai peserta, mengupload atau memasukkan data berkas.

2) Bagian kemahasiswaan: mempunyai hak akses untuk mem-posting publikasi, melakukan validasi berkas, dan membuat laporan data peserta.

3) Juri: mempunyai hak akses untuk menilai berkas pada tahap awal, tahap akhir (pada saat wawancara). 
4) Wakil Dekan I: yang mempunyai hak akses untuk menerima laporan data peserta, dan membuat laporan hasil laporan peserta.

Pada halaman utama sistem, ditampilkan informasi umum terkait dengan kegiatan pemilihan mahasiwa berprestasi di Fakultas Vokasi Universitas Airlangga, misalnya tanggal pengumpulan berkas, berkas apa saja yang harus dikumpulkan, tanggal dilakukan proses seleksi, dan tanggal pengumuman pemenang. Halaman untuk peserta digunakan untuk mahasiswa yang akan menjadi peserta dalam pemilihan Mawapres. Mahasiswa sebelum mengisi formulir pendaftaran yang ada di dalam aplikasi harus mendapat username dan password dari admin. Setelah peserta berhasil login dengan memasukkan username dan password, peserta bisa nengisi formulir pendaftaran. mengunggah foto, memasukkan data prestasi yang diunggulkan, dan karya ilmiah baik berupa file doc atau video. Juri untuk setiap kriteria mempunyai hak akses sesuai dengan kriteria yang akan dinilai oleh juri tersebut, antara lain Juri Bahasa Inggris, Juri Karya Ilmiah, dan Juri Prestasi. Setiap juri mempunyai menu untuk menilai tahap awal dan tahap akhir.

Evaluasi sistem dilakukan dengan menerapkan acceptance testing. Evaluasi ini dilakukan dengan menggunakan kuesioner yang diberikan ke pengguna sistem. Kuesioner berisi pernyataan untuk mengetahui apakah user interface mudah dipahami dan interaktif, apakah aplikasi mudah digunakan, serta apakah program dapat membantu dalam memberi bahan pertimbangan dalam pengambilan kebijakan. Dalam penelitian ini, kuesioner diberikan kepada 3 orang, yaitu 1 orang adalah kasubag kemahasiswaan dan 2 orang adalah juri pada kegiatan yang telah dilakukan sebelumnya.

Berdasarkan hasil evaluasi sistem dapat disimpulkan bahwa seluruh fitur pada sistem informasi pemilihan Mawapres telah berjalan dengan baik dan benar, dan dapat diterima oleh pengguna. Dengan adanya sistem, para pengguna juga merasa dimudahkan tugasnya dalam kegiatan pemilihan ini.

Aplikasi juga telah diperbaiki sesuai dengan masukan pengguna. Perbaikan yang dilakukan antara lain: ditambahkannya gambar, poster, dan informasi terkait kegiatan pemilihan Mawapres. Perbaikan juga dilakukan dengan menambahkan fasilitas untuk upload foto, file dan video karya ilmiah peserta. Perbaikan yang belum dilakukan adalah ditambahkannya proses seleksi awal terhadap peserta, yaitu lolos atau gugurnya peserta ke tahap selanjutnya. Hal ini disebabkan karena untuk proses ini membutuhkan kebijakan yang tersendiri. Sampai saat ini dari dua kali kegiatan yang pernah dilaksanakan, seleksi tahap awal belum pernah dilakukan karena pesertanya tidak terlalu banyak.

\section{KESIMPULAN}

Sistem yang dikembangkan selain mampu memberikan perangkingan Mawapres sesuai dengan aturan Dikti (metode standard), juga memberikan perangkingan dengan metode TOPSIS dan Fuzzy TOPSIS (dengan data campuran crisp dan fuzzy). Dengan menggunakan data 10 mahasiswa yang ikut berkompetisi pada tahun 2016, sistem ini memberikan hasil pengurutan yang berbeda, Adanya perbedaan hasil perangkingan, dapat memberikan masukan kepada pimpinan fakultas untuk dasar pengambilan keputusan. Dengan masukan ini diharapkan pimpinan fakultas bisa mengambil keputusan dengan lebih baik.

Berdasarkan hasil evaluasi sistem dapat disimpulkan bahwa seluruh fitur pada sistem telah berjalan dengan baik dan benar, dan dapat diterima oleh pengguna. Dengan digunakannya sistem ini, akan memudahkan kerja juri dan panitia yang terlibat dalam kegiatan pemilihan Mawapres di Fakultas. Sistem Sistem ini nantinya bisa juga dimodifikasi dan dimanfaatkan untuk menentukan lulusan terbaik yang selalu dilakukan menjelang kegiatan wisuda.

\section{UCAPAN TERIMA KASIH}

Penulis mengucapkan terima kasih kepada Fakultas Vokasi Universitas Airlangga yang telah memberi dukungan finansial melalui Hibah Penelitian Terapan dengan nomor kontrak 1128/UN3.1.14/LT/2016.

\section{DAFTAR PUSTAKA}

Alavi, I., \& Alinajed-Rokny, H. (2011). Comparison of Fuzzy AHP and Fuzzy TOPSIS Methods for Plant Species Selection (Case Study: Reclamation Plan of Sungun Copper Mine;Iran). Ausitralian Journal of Basic and Applied Sciences, 5(12), 1104-1113.

Awasthi, A., Chauhan, S., \& Goyal, S. (2011). A Multi-Criteria Decision Making Approach for Location Planning for Urban Distribution Centers Under Uncertainty. Mathematical \& Computer Modelling, 53(1-2), 98-109.

Azizi, A. Aikhuele, D. O., \& Fathi S. Souleman, F. (2015). A Fuzzy TOPSIS Model to Rank Automotive Suppliers. Procedia Manufacturing, 159-164.

BELMAWA RISTEKDIKTI. (2016). Pedoman Pemilihan Berprestasi Program Diploma. Jakarta: Direktorat Jendral Pembelajaran dan Kemahasiswaan Kementerian Riset Teknologi dan Pendidikan Tinggi. 
Chen, C., Lin, C., \& Huang, S. (2006). A Fuzzy approach for supplier Evaluation and selection in supply chain management. International Journal of Production Economics, 102(2006), 289-301.

Chu, T., \& Lin, Y. (2003). A Fuzzy TOPSIS Method for Robot Selection. International Journal of Advanced Manufacturing Technology, 21, 284-290.

Herawatie, D., \& Wuryanto, E. (2016). Pemilihan Mahasiswa Berprestasi Diploma dengan Menggunakan Metode TOPSIS. SEMNASTIKOM 2016. Mataram.

Hung, C., \& Chen, L. (2009). A Fuzzy TOPSIS Decision Making Model with Entropy Weight under Intuitionistic Fuzzy Environment. the International MultiConference of Engineers and Computer Scientists IMECS. Hong Kong.
Kabir, G., \& Hasin, M. (2012). Comparative Analysis of TOPSIS and Fuzzy TOPSIS fir the Evaluation of Travel Website Service Quality. Quality Research, 6, 169-185.

Liao, C.-N., \& Kao, H.-P. (2011). An Integrated fuzzy TOPSIS and MCCP approach to Supplier selection in Supply Chain Management. Expert Systems with Application, 38, 10803 - 10811.

Uyun, S., \& Riadi, I. (2011). A Fuzzy Topsis Multiple-Attribute Decision Making for Scholarship Selection. TELKOMNIKA, 9(1), 37-46.

Wimatsari, G. A., Ketut, G. D., \& Putu, W. B. (2013). Multi-attribute decision making scholarship selection using a modified fuzzy TOPSIS. International Journal of Computer Science, 10(1), 309-317. 